\title{
Effects of different heat treatments on the antioxidant activity and ascorbic acid content of bitter melon, Momordica charantia
}

\author{
Efeitos de diferentes tratamentos térmicos na atividade \\ antioxidante e no conteúdo de ácido ascórbico de melão \\ amargo (Momordica charantia)
}

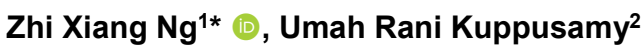 \\ ${ }^{1}$ University of Nottingham Malaysia, Faculty of Science and Engineering, School of Biosciences, Selangor - \\ Malaysia \\ ${ }^{2}$ University of Malaya, Faculty of Medicine, Department of Biomedical Science, Kuala Lumpur - Malaysia
}

*Corresponding Author: Zhi Xiang Ng, University of Nottingham Malaysia, Faculty of Science and Engineering School of Biosciences, 43500, Selangor - Malaysia, e-mail: ZhiXiang.Ng@nottingham.edu.my; ngzx_86@yahoo.com

Cite as: Ng, Z. X., \& Kuppusamy, U. R. (2019). Effects of different heat treatments on the antioxidant activity and ascorbic acid content of bitter melon, Momordica charantia. Brazilian Journal of Food Technology, 22, e2018283. https://doi.org/10.1590/1981-6723.28318

\begin{abstract}
This study investigated the effects of different heat treatments, namely boiling, microwaving and pressure cooking, on the reduced ascorbic acid content and antioxidant activity in Momordica charantia extracts. The total antioxidant activity of M. charantia extracts was determined by ferric reducing-antioxidant power and 2,2-diphenyl-1-picrylhydrazyl radical scavenging assays. The reduced ascorbic acid content was estimated by ferric reducing-antioxidant power-ascorbic acid assay and confirmed by high performance liquid chromatography. Regardless of the cooking method, all cooked M. charantia extracts had significantly $(p<0.05)$ higher total antioxidant activity, radical scavenging potency and reduced ascorbic acid content than the uncooked sample. The decreasing order of reduced ascorbic acid in M. charantia was as follows: microwaved $>$ boiled $>$ pressure-cooked $>$ uncooked. The reduced ascorbic acid in $M$. charantia strongly correlated with the total antioxidant activity $(r=0.958, p<0.05)$ and radical scavenging potency $(r=0.951, p<0.05)$. The principle component analysis showed that $87 \%$ of the variation in the antioxidant values of $M$. charantia extracts was attributed to the different cooking methods. Heat treatment either by boiling or microwaving for a short period of time (10 minutes) improved the reduced ascorbic acid content in the M. charantia extract. This study showed that the reduced ascorbic acid could be retained under high temperature and pressure in $M$. charantia extracts.
\end{abstract}

Keywords: Ascorbic acid; Antioxidant activity; Thermal processing; High performance liquid chromatography; Momordica charantia. 


\section{Resumo}

Este estudo investiga o efeito de diferentes tratamentos térmicos, a saber, fervura, cozimento em micro-ondas e cozimento sob pressão sobre o ácido ascórbico e a atividade antioxidante no extrato de Momordica charantia. A atividade antioxidante total dos extratos de M. charantia foi determinada pelo poder redutor-antioxidante férrico e pelos ensaios de eliminação de radicais 2,2-difenil-1-picrifirazol. O teor de ácido ascórbico foi estimado pelo ensaio de redução do poder férrico-antioxidante-ácido ascórbico e confirmado por cromatografia líquida de alta eficiência. Independentemente do método de cocção, todos os extratos de $M$. charantia cozidos apresentaram $(p<0,05)$ maior atividade antioxidante total, potência de eliminação de radicais livres e teor de ácido ascórbico, quando comparados com a amostra não tratada termicamente. A ordem decrescente de ácido ascórbico reduzido em M. charantia foi a seguinte: micro-ondas > fervura > cozimento sob pressão > não tratado termicamente. $\mathrm{O}$ ácido ascórbico reduzido em $M$. charantia correlacionou-se fortemente com a atividade antioxidante total $(r=0,958, p<0,05)$ e potência de eliminação de radicais livres $(r=0,951, p<0,05)$. A análise dos componentes principais mostrou que $87 \%$ de variação nos valores antioxidantes do extrato de $M$. charantia foi atribuída aos diferentes métodos de cozimento. $O$ tratamento térmico por ebulição ou micro-ondas por um curto período de tempo (10 minutos) melhorou o teor de ácido ascórbico reduzido no extrato de $M$. charantia. Este estudo mostra que o ácido ascórbico pode ser retido sob alta temperatura e pressão no extrato de $M$. charantia.

Palavras-chave: Ácido ascórbico; Atividade antioxidante; Processamento térmico; Cromatografia líquida de alta performance; Momordica charantia.

\section{Introduction}

Antioxidants are chemical compounds that prevent or delay the oxidation of other molecules either by scavenging or preventing free radical formation (Apak et al., 2007). The natural antioxidants found in fruits and vegetables, such as polyphenols, are reported to correlate with the reduced risk of chronic human diseases such as cancer, cardiovascular diseases, hypertension and diabetes mellitus (Zhang \& Hamauzu, 2004). Ascorbic acid is commonly known as vitamin C. This water-soluble antioxidant protects the cell membrane against lipid oxidation and helps to regenerate other antioxidants (Valko et al., 2006). In fresh fruits and vegetables, the most common form of ascorbic acid is L-ascorbic acid (L-AA) (Munyaka et al., 2010).

The introduction of the heat treatment of fruits and vegetables has been reported to affect the nutritional content and antioxidant activity of the fruits and vegetables (Zhang \& Hamauzu, 2004). Previously, the present authors showed that the appropriate heat treatment may improve or preserve the nutritional values of selected vegetables and mushrooms (Ng et al., 2011; Ng \& Rosman, 2019; Ng \& Tan, 2017). Interestingly, boiling significantly increased the phenolic content ( $>30 \%)$ and total antioxidant activity $(>200 \%)$ of bitter melon (Momordica charantia). Although the phenolic content was shown to be a significant contributor to the antioxidant activity of the cooked $M$. charantia extracts, the total antioxidant activity determined was higher than could be explained on the basis of the phenolic content, and the authors did not exclude the likelihood that the high antioxidant activity detected in the cooked $M$. charantia extracts could also be attributed to L-AA, since M. charantia is rich in L-AA (Grover \& Yadav, 2004).

Since L-AA is more labile than other antioxidants, its concentration in fruits and vegetables could be altered by different heat treatments such as cooking (Munyaka et al., 2010). In the Asian cuisine, M. charantia is usually cooked by different methods prior to consumption, such as steaming, microwaving and boiling. The aim of this study was to investigate the effects of different types of wet heat treatments, namely boiling, microwaving and pressure cooking on the L-AA content of $M$. charantia extracts, and to determine the contribution of L-AA to the antioxidant activity of the cooked M. charantia extracts. The findings of this study could provide an insight to the heat processing techniques that could preserve the L-AA and antioxidant activity in the fruits and vegetables. 


\section{Material and methods}

\subsection{Chemicals}

All the chemicals used in this study were of analytical grade except for those used in the HPLC analysis. Absolute methanol $\left(\mathrm{CH}_{4} \mathrm{O}\right)$, ethanol $\left(\mathrm{C}_{2} \mathrm{H}_{6} \mathrm{O}\right)$, fuming hydrochloric acid $(\mathrm{HCl})$, glacial acetic acid $\left(\mathrm{C}_{2} \mathrm{H}_{4} \mathrm{O}_{2}\right)$ and ferric (III) chloride hexahydrate $\left(\mathrm{FeCl}_{3} \bullet 6 \mathrm{H}_{2} \mathrm{O}\right)$, were purchased from Merck (Darmstadt, Germany). Ferrous (II) sulphate heptahydrate $\left(\mathrm{FeSO}_{4} \bullet 7 \mathrm{H}_{2} \mathrm{O}\right)$, L-ascorbic acid, L-ascorbic oxidase (EC 1.10.3.3), sodium acetate trihydrate $\left(\mathrm{C}_{2} \mathrm{H}_{3} \mathrm{NaO}_{2} \cdot 3 \mathrm{H}_{2} \mathrm{O}\right)$, 2,2-diphenyl-1-picrylhydrazyl (DPPH) and 2,4,6-tri-(2-pyridyl)-1,3,5triazine (TPTZ) were purchased from Sigma-Aldrich (St. Louis, MO, USA).

\subsection{Sample preparation and processing}

Bitter melons (Momordica charantia) (approximately $2000 \mathrm{~g}$ ) were purchased from TESCO ${ }^{\mathrm{TM}}$ Extra hypermarket in Seremban, Malaysia and processed as previously described (Ng et al., 2011, 2014). Briefly, the seeds were removed, and the edible parts of the fruits washed, dab dried and sliced into small pieces prior to weighing. $150 \mathrm{~g}$ of sample in $200 \mathrm{~mL}$ of distilled water were used for each cooking method. A cooking time of 10 minutes was applied to simulate the usual domestic cooking processes (Suresh et al., 2007). For microwave cooking, the vegetable sample was microwaved in the centre position of a commercial $1000 \mathrm{~W}$ domestic microwave oven (model: NN-CT579S, Panasonic Co., Osaka, Japan) at a high power setting operating of $2450 \mathrm{MHz}$ for 10 minutes. For boiling, a hot plate was used to boil the vegetable at $100{ }^{\circ} \mathrm{C}$ for 10 minutes and the water temperature was monitored using a mercury thermometer. For pressure cooking, the vegetable was pressure cooked in a commercial pressure cooker (model: Buffalo QWP403, Ni Hsin Co. Sdn Bhd, Selangor, Malaysia) at a high pressure setting (15 pounds per square inch or $103.4 \mathrm{kPa}$ ) at $121{ }^{\circ} \mathrm{C}$ for 20 minutes (including 5 minutes for the water to boil, 10 minutes of cooking and 5 minutes for the release of the steam pressure). The glass beakers were loosely covered to prevent water evaporation during cooking. The internal temperatures of the boiled, microwaved and pressure-cooked vegetable samples (triplicates), measured using a digital food thermometer, were $79.3 \pm 1.1^{\circ} \mathrm{C}, 84.3 \pm 1.6^{\circ} \mathrm{C}$ and $72.4 \pm 0.9^{\circ} \mathrm{C}$ respectively. All the cooked vegetable samples were cooled rapidly on ice to prevent further cooking by the residual heat. The cooked vegetable samples were homogenised with the cooking water in an electric blender. For the raw (uncooked) control samples, $150 \mathrm{~g}$ of the vegetable were homogenized in $200 \mathrm{~mL}$ of distilled water. The homogenates were filtered through cheese cloth and centrifuged at $2400 \mathrm{xg}$ for 15 minutes. The clear vegetable extracts were freeze dried and maintained at $-20{ }^{\circ} \mathrm{C}$ until analysed. The freeze dried extracts were reconstituted with distilled water and analysed in triplicate in a single run.

\subsection{Ferric-reducing Antioxidant Power (FRAP) assay}

The total antioxidant activities of the M. charantia extracts were determined by the FRAP assay according to Benzie \& Strain (1996). A standard curve was prepared using a ferrous sulphate solution $(0-1000 \mu \mathrm{M})$. The FRAP values were expressed as mmol ferrous sulphate equivalent per $100 \mathrm{~g}$ freeze dried extract (mmol FE/100 g).

\subsection{2,2-Diphenyl-1-picryl-hydrazyl (DPPH) radical scavenging assay}

The radical scavenging activities of the $M$. charantia extracts were determined using DPPH radicals as outlined by Gerhäuser et al. (2003). A standard curve was prepared using a L-AA solution (0-1000 $\mu \mathrm{M})$. The half maximal inhibitory concentration $\left(\mathrm{IC}_{50}\right)$ for the L-AA standard was $23.45 \mathrm{mmol} / \mathrm{l}$. The DPPH radical scavenging activity was expressed as the percentage inhibition of the DPPH radicals (\%). 


\subsection{Ferric-reducing antioxidant power-ascorbic acid (FRASC) assay}

The L-AA contents of the M. charantia extracts were determined according to Szeto et al. (2002) with some modifications. In a paired treatment, the $M$. charantia extracts $(100 \mu \mathrm{lof} 5 \mathrm{mg} / \mathrm{mL})$ were incubated with and without L-ascorbic acid oxidase (L-AAO) (EC 1.10.3.3) $(5 \mathrm{IU} / \mathrm{mL})$ at $37^{\circ} \mathrm{C}$ for 5 minutes, and then chilled on ice to terminate the L-AAO reaction. The total antioxidant activities of the samples were then determined using the FRAP assay. The difference in the absorbance values between the L-AAO treated and untreated $M$. charantia extracts corresponded to the L-AA content in the sample extracts. A standard curve was prepared using a L-AA solution $(0-150 \mu \mathrm{g} / \mathrm{mL})$ in order to calculate the L-AA content of the $M$. charantia extracts. The L-AA content was expressed as mg per $100 \mathrm{~g}$ of freeze dried extract $(\mathrm{mg} / 100 \mathrm{~g})$.

\subsection{HPLC analysis of the L-AA}

The L-AA content was confirmed using high performance liquid chromatography (HPLC) according to De Quirós et al. (2001), with some modifications. The $M$. charantia extracts $(5 \mathrm{mg} / \mathrm{mL})$ were reconstituted using distilled water and filtered before the HPLC analysis. The filtered extracts $(20 \mu \mathrm{L})$ were injected into an HPLC system (Waters Delta Prep, Waters Co., Milford, Massachusetts, United States) equipped with a dual $\lambda$ absorbance detector (ultraviolet detector), and a Purospher STAR column (100 mm x $4.6 \mathrm{~mm}$ I.D. Purospher, $5 \mu \mathrm{m}$, LiChrocart RP-18) (Merck ${ }^{\circledR}$ KGaA, Darmstadt, Germany), and using HPLC-grade methanol/water $(15 / 85 ; \mathrm{v} / \mathrm{v})$ as the mobile phase at a flow rate of $0.90 \mathrm{~mL} / \mathrm{min}$. The chromatograms were recorded at $254 \mathrm{~nm}$ and an external linear L-AA standard curve $\left(R^{2}=0.9367\right)$ was used to quantify the L-AA in the raw (uncooked) and cooked M. charantia extracts (Figure 1). The L-AA standards used for quantification ranged from 0.50 to $20.0 \mu \mathrm{g} / \mathrm{mL}$ (Figure 1a), based on the area under the peak. The L-AA content was expressed as $\mathrm{mg}$ per $100 \mathrm{~g}$ of freeze dried extract $(\mathrm{mg} / 100 \mathrm{~g})$.

(a)

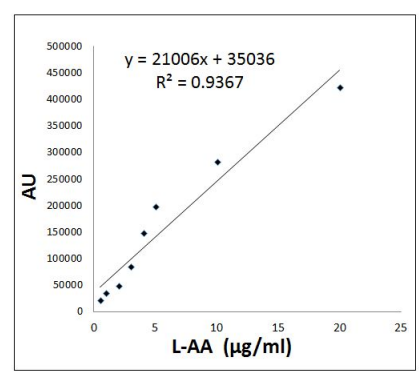

(d)

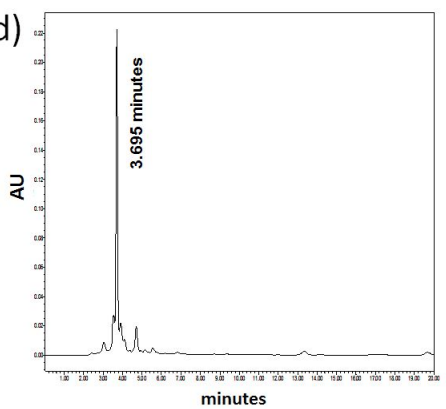

(b)

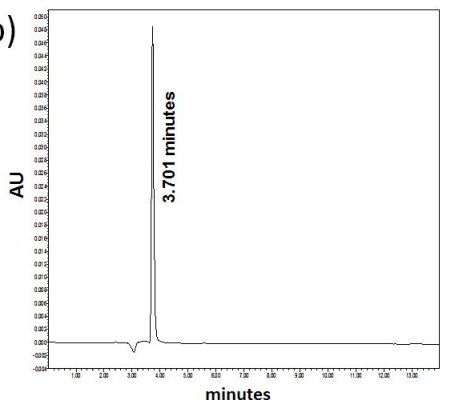

(e)

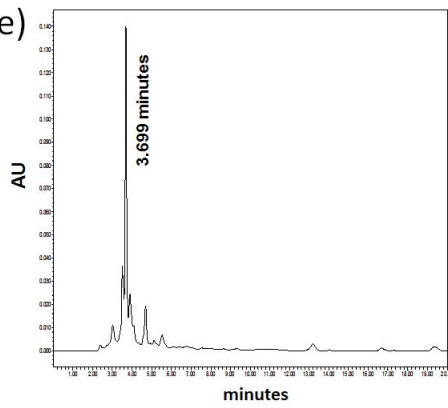

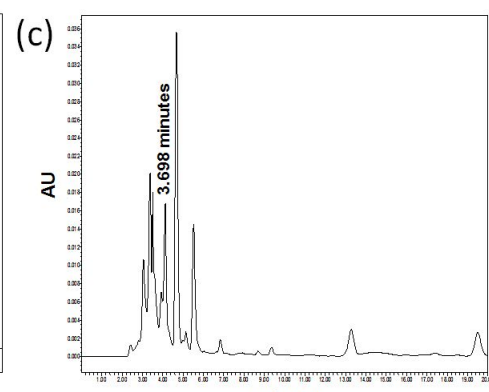

minutes

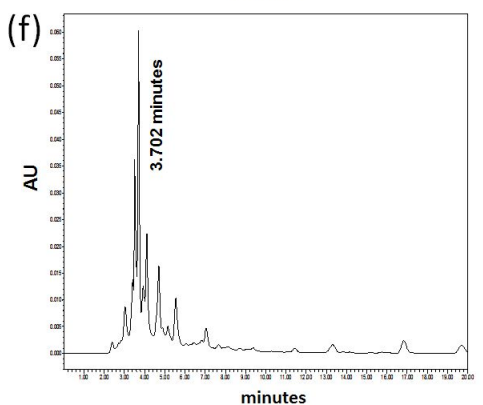

Figure 1. HPLC analysis of L-AA in the M. charantia extracts (a) 8-point standard calibration curve (b) L-AA standard $20 \mu \mathrm{g} / \mathrm{mL}$ (c) raw sample (d) boiled sample (e) microwaved sample (f) pressure cooked sample. AU denotes arbitrary units. 


\subsection{Statistical analysis}

All the data were expressed as the mean \pm standard deviation (SD) (triplicates). The differences between the means for the antioxidant activities and L-AA contents of the M. charantia subjected to the different heat treatments, were evaluated by a ONE-WAY ANOVA with Tukey's post hoc test, and the association of L-AA with the antioxidant activity was analysed by Pearson's correlation test. The original variables in the samples cooked by the different methods and their antioxidant activities were subjected to the Principal Component Analysis (PCA) by transforming them into a new set of principal components which determine their contribution towards the variation in the whole data set. The statistical significance was set at a p-value of less than 0.05. All analyses were carried out using the GraphPad Prism ${ }^{\circledR}$ for Windows ${ }^{\circledR}$ version $6.0\left(\mathrm{GraphPad}^{\circledR}\right.$ Software Inc., San Diego, CA, U.S.A) and XLSTAT 2014 software for Microsoft Excel program (Addinsoft Inc., New York, NY, USA).

\section{Results and discussion}

Amongst the plant organs, the fruit is the main source of ascorbic acid followed by the leaf (Asensi-Fabado \& Munné-Bosch, 2010). M. charantia, a fruit commonly found in tropical areas of Asia, Africa and Amazon, has been regarded as a food and medicinal plant (Grover \& Yadav, 2004). L-AA is commonly found in the cytosols, cell walls, vacuoles, chloroplasts, apoplasts and mitochondria (Munyaka et al., 2010). As a potent cellular antioxidant, L-AA has excellent reactive oxygen species scavenging properties (Asensi-Fabado \& Munné-Bosch, 2010) but is vulnerable to non-enzymatic and enzymatic degradation. It can be oxidized to dehydroascorbic acid by ascorbic acid peroxidase (EC 1.11.1.11) and L-ascorbic acid oxidase (L-AAO) (EC 1.10.3.3), commonly found in the cell wall, extracellular matrix and vacuoles (Munyaka et al., 2010). Table 1 shows the extraction efficiencies, antioxidant activities and L-AA contents of the raw (uncooked) and cooked $M$. charantia samples. Boiling and microwaving significantly increased the total antioxidant activities (FRAP values) of the $M$. charantia samples. In addition, the radical scavenging potency of the microwave-cooked $M$. charantia extract also showed a similar increasing trend. In the present study, the L-AA content determined by HPLC (Figure 1) in the raw (uncooked) M. charantia $(82.0 \pm 2.9 \mathrm{mg} / 100 \mathrm{~g})$ was similar to the levels reported in other studies, which were $79.8 \pm 9.3 \mathrm{mg} / 100 \mathrm{~g}$ (Malik et al., 2011) and $72.5 \pm 22.3 \mathrm{mg} / 100 \mathrm{~g}$ (Somsub et al., 2008). Although higher levels of L-AA were detected in all the samples using the HPLC method when compared to the FRASC assay, the order of the L-AA contents for the cooked M. charantia extracts remained the same: microwaved $>$ boiled $>$ pressure-cooked $>$ uncooked (Table 1). HPLC is a better analytical tool to quantify the L-AA when compared to the FRASC assay. However, the FRASC assay provides an alternative tool for the simple and fast screening of the L-AA content in biological fluids.

Table 1. Extraction efficiencies, antioxidant activities and reduced ascorbic acid (L-AA) contents of the M. charantia extracts submitted to different wet heat treatments.

\begin{tabular}{|c|c|c|c|c|c|c|}
\hline \multirow[b]{2}{*}{$\begin{array}{l}\text { M. charantia } \\
\text { samples }\end{array}$} & \multicolumn{2}{|c|}{ Extraction efficiency } & \multicolumn{2}{|c|}{ Antioxidant activity } & \multicolumn{2}{|c|}{ L-AA } \\
\hline & $\begin{array}{l}\text { Freeze dried } \\
\text { extract }(g)\end{array}$ & Percentage ${ }^{\#}$ & $\begin{array}{c}\text { FRAP } \\
(\mathrm{mmol} \mathrm{FE} / 100 \mathrm{~g})\end{array}$ & $\begin{array}{c}\text { DPPH }{ }^{\#} \\
(\% \\
\text { scavenging })\end{array}$ & $\begin{array}{l}\text { FRASC } \\
(\mathrm{mg} / 100 \mathrm{~g})\end{array}$ & $\begin{array}{c}\text { HPLC } \\
(\mathrm{mg} / 100 \mathrm{~g})\end{array}$ \\
\hline Raw (uncooked) & 2.5 & 1.6 & $2.7 \pm 0.1^{\mathrm{a}}$ & $5.1 \pm 0.3^{\mathrm{a}}$ & $20.0 \pm 6.9^{a}$ & $82.0 \pm 2.9^{\mathrm{a}}$ \\
\hline Boiled & 3.7 & 2.5 & $8.7 \pm 0.5^{b}$ & $7.0 \pm 2.4^{\mathrm{a}}$ & $496.0 \pm 10.6^{b}$ & $550.6 \pm 25.9^{b}$ \\
\hline Microwaved & 2.0 & 1.3 & $7.8 \pm 0.3^{b}$ & $9.1 \pm 1.7^{b}$ & $514.7 \pm 68.4^{b}$ & $671.3 \pm 21.1^{c}$ \\
\hline Pressure cooked & 2.5 & 1.7 & $3.3 \pm 0.1^{\mathrm{a}}$ & $5.4 \pm 1.9^{a}$ & $54.7 \pm 4.6^{\mathrm{a}}$ & $159.3 \pm 27.3^{d}$ \\
\hline
\end{tabular}

Values presented as the mean value \pm SD $(n=3)$ unless otherwise indicated. "\#Te extraction efficiency percentage of the freeze dried extract was calculated based on the amount of fresh sample used $(150 \mathrm{~g}) .{ }^{\#}$ The half maximal inhibitory concentration $\left(\mathrm{IC}_{50}\right)$ for the ascorbic acid standard was $23.45 \mathrm{mmol} / \mathrm{l}$. Values in the same column followed by different superscript letters are significantly different $(p<0.05)$.

Interestingly, a significant increase in L-AA content was detected in the $M$. charantia samples after pressure cooking, microwaving and boiling, when compared to the raw (uncooked) sample (Table 1). This 
was in agreement with another recent finding (Subramaniam et al., 2017). A previous study showed that heat attenuated the antioxidant capacity and caused a loss of ascorbic acid in several cooked vegetables (Zhang \& Hamauzu, 2004; Somsub et al., 2008). In the present study, the increased L-AA contents in the pressurecooked, microwaved and boiled M. charantia samples, as compared to the raw (uncooked) sample, could be attributed to matrix softening by the heat, resulting in greater extractability of the L-AA. Munyaka et al. (2010) showed that L-AAO was completely inactivated in vegetables cooked for 10 minutes above $70{ }^{\circ} \mathrm{C}$, and this was further supported by a recent similar finding (Wawire et al., 2011). Therefore, the inactivation of L-AAO and other L-AA oxidizing enzymes in the cooked vegetable could contribute to the stability of the L-AA in the cooked M. charantia. The low L-AA content in the raw (uncooked) M. charantia extract could be due to the enzymatic degradation of L-AA to dehydroascorbic acid during the processing of the vegetable at a temperature below $70{ }^{\circ} \mathrm{C}$. However, the L-AA content was significantly lower in the pressure-cooked sample when compared to the boiled and microwaved samples, due to the different heating mechanisms involved in pressure cooking and the degradative effect of prolonged heat treatment (20-minute pressure cooking) on the L-AA. Nevertheless, the L-AA of the pressure-cooked sample was higher than that of the raw (uncooked) sample (Table 1).

In the correlation analysis, the L-AA was strongly correlated with the total antioxidant activity $(r=0.958$, $\left.\mathrm{R}^{2}=0.917, p<0.05\right)$ and the DPPH radical scavenging potency $\left(r=0.951, \mathrm{R}^{2}=0.905, p<0.05\right)$. This finding supports the contribution of the L-AA to the total antioxidant activity and free radical scavenging potency observed in the raw and cooked $M$. charantia extracts. The above strong correlation also suggests the good reducing power and radical scavenging potency of the L-AA. However, there is also the possibility that the improvement in the total antioxidant activity in the cooked $M$. charantia extracts could be attributed to the interaction of other antioxidant compounds not investigated in this study, such as the Maillard products, polyphenols and antioxidant enzymes. A previous study showed that customised cooking could induce the extraction of water-soluble phenolic compounds from the tissues of M. charantia (Ng et al., 2011). The upregulation of several antioxidant enzymes such as superoxide dismutase and quinone oxidoreductase during heat stress could also contribute to the increased antioxidant activity observed in the cooked M. charantia samples (Ng et al., 2014).

The main sources of variability in the M. charantia extracts were evaluated using PCA by focusing on the relationship between the antioxidant activity variables (FRAP, DPPH and L-AA) and sample treatment (different heat treatments) (Figure 2). The results, shown as a biplot (score plot and loading plot), depicted the distribution and correlation of the samples with the four original variables in two principle components. The first principle component (F1, $\mathrm{x}$-axis) and second principle component (F2-y-axis) corresponded to the largest cumulative variance of $98 \%$ in the original variables. The first principal component separated the raw (uncooked) and pressure cooked bitter melon samples (negative area) from the boiled and microwaved counterparts (positive area). This finding shows that in this study, $87 \%$ of the variation corresponding to the antioxidant values of the sample, was attributed to the cooking effect. This was in agreement with Domínguez et al. (2014), who reported that the changes in nutrient composition in cooked foods were mainly dependent on the heat and mass transfer in the different cooking methodologies. 
Biplot (axes F1 and F2: $98.02 \%$ )

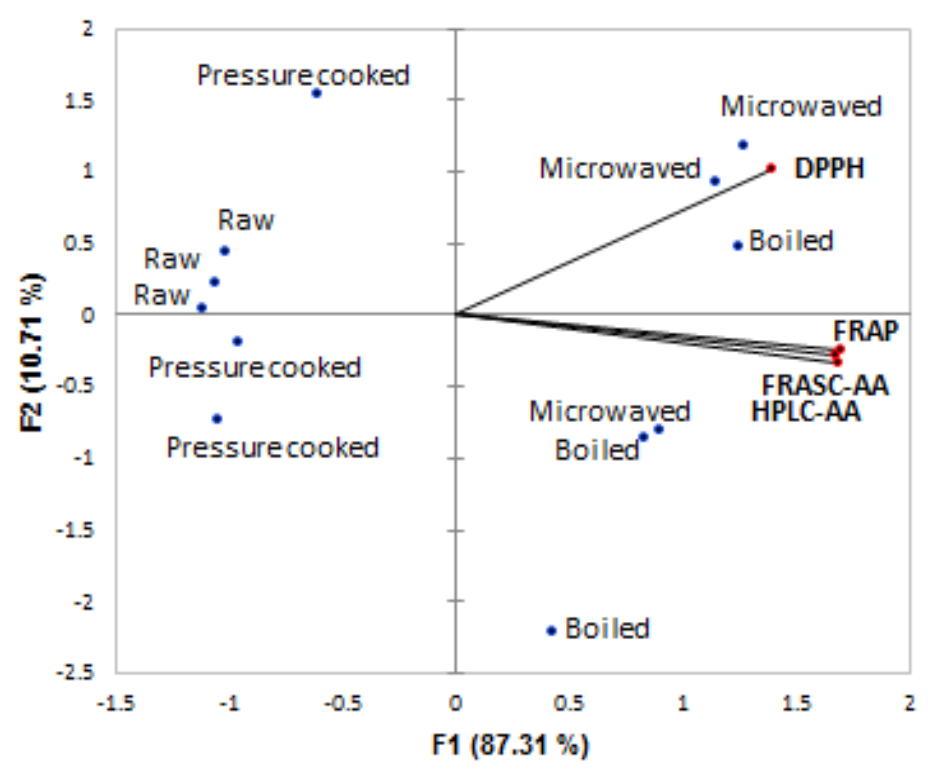

Figure 2. Principal component analysis map showing the relationships between the different types of $M$. charantia sample (raw, boiled, microwaved and pressure-cooked) and the antioxidant activities. DPPH = 2,2-Diphenyl-1-picrylhydrazyl radical scavenging activity; FRAP $=$ Ferric reducing antioxidant power; FRASC-AA $=$ ferric reducing antioxidant power-ascorbic acid; HPLC-AA = High performance liquid chromatography-ascorbic acid.

On the contrary, a clear separation of DPPH radical scavenging value from the other antioxidant values (FRAP and L-AA) in the second principle component made up $11 \%$ of the observed variation. This can be explained by the different mechanisms (DPPH versus FRAP) used to measure in vitro sample antioxidant activity in this study (Ng \& See, 2019). Nevertheless, the FRAP and L-AA variables (FRASC-AA and HPLC-AA) showed similar vector directions, indicating a strong relationship between these values. Amongst the different cooked samples, the boiled and microwaved samples showed stronger positive correlations with the antioxidant values (FRAP, DPPH and L-AA) when compared to the raw and pressure cooked samples. The PCA data in this study confirmed that the main variation in the antioxidant activities observed in the M. charantia extracts was dependent on the different heat treatment applied.

\section{Conclusion}

This study provided evidence that heat treatment either by boiling or microwaving for a short period of time (10 minutes) improved the L-AA content of the $M$. charantia extracts. It also showed that the L-AA content of $M$. charantia could be retained under high temperature and pressure. The effects of different temperatures and pressures on the stability of both L-AA and other L-AA oxidizing enzymes in other vegetables deserve further investigation. The findings of this study could serve as a reference for both the domestic and industrial heat processing of fruits and vegetables, particularly $M$. charantia, in preserving their nutritional value.

\section{Acknowledgement}

Authors wish to thank Ms Jaime Stella Richardson and Professor Sri Nurestri Abdul Malek for their assistance in the HPLC analysis. 


\section{References}

Apak, R., Guclu, K., Demirata, B., Ozyurek, M., Celik, S. E., Bektasoglu, B., Berker, K. I., \& Ozyurt, D. (2007). Comparative evaluation of various total antioxidant capacity assays applied to phenolic compounds with the CUPRAC assay. Molecules, 12(7), 1496-1547. PMid:17909504. http://dx.doi.org/10.3390/12071496

Asensi-Fabado, M. A., \& Munné-Bosch, S. (2010). Vitamins in plants: Occurrence, biosynthesis and antioxidant function. Trends in Plant Science, 15(10), 582-592. PMid:20729129. http://dx.doi.org/10.1016/j.tplants.2010.07.003

Benzie, I. F., \& Strain, J. J. (1996). The ferric reducing ability of plasma (FRAP) as a measure of "antioxidant power": The FRAP assay. Analytical Biochemistry, 239(1), 70-76. PMid:8660627. http://dx.doi.org/10.1006/abio.1996.0292

De Quirós, A., Lopez-Hernandez, J., \& Simal-Lozano, J. (2001). Determination of vitamin C in sea urchin: Comparison of two HPLC methods. Chromatographia, 53, S246-S249. http://dx.doi.org/10.1007/BF02490336

Domínguez, R., Gomez, M., Fonseca, S., \& Lorenzo, J. M. (2014). Effect of different cooking methods on lipid oxidation and formation of volatile compounds in foal meat. Meat Science, 97(2), 223-230. PMid:24583332.

http://dx.doi.org/10.1016/j.meatsci.2014.01.023

Gerhäuser, C., Klimo, K., Heiss, E., Neumann, I., Gamal-Eldeen, A., Knauft, J., Liu, G. Y., Sitthimonchai, S., \& Frank, N. (2003). Mechanism-based in vitro screening of potential cancer chemopreventive agents. Mutation Research, 523-524, 163-172. PMid:12628514. http://dx.doi.org/10.1016/S0027-5107(02)00332-9

Grover, J. K., \& Yadav, S. P. (2004). Pharmacological actions and potential uses of Momordica charantia: A review. Journal of Ethnopharmacology, 93(1), 123-132. PMid:15182917. http://dx.doi.org/10.1016/j.jep.2004.03.035

Malik, Z. A., Singh, M., \& Sharma, P. L. (2011). Neuroprotective effect of Momordica charantia in global cerebral ischemia and reperfusion induced neuronal damage in diabetic mice. Journal of Ethnopharmacology, 133(2), 729-734. PMid:21056650. http://dx.doi.org/10.1016/j.jep.2010.10.061

Munyaka, A. W., Makule, E. E., Oey, I., Van Loey, A., \& Hendrickx, M. (2010). Thermal stability of L-ascorbic acid and ascorbic acid oxidase in broccoli (Brassica oleracea var. italica). Journal of Food Science, 75(4), C336-C340. PMid:20546391. http://dx.doi.org/10.1111/j.1750-3841.2010.01573.x

Ng, Z. X., Chai, J. W., \& Kuppusamy, U. R. (2011). Customized cooking method improves total antioxidant activity in selected vegetables. International Journal of Food Sciences and Nutrition, 62(2), 158-163. PMid:21250903. http://dx.doi.org/10.3109/09637486.2010.526931

Ng, Z. X., Chua, K. H., \& Kuppusamy, U. R. (2014). Proteomic analysis of heat treated bitter gourd (Momordica charantia L. var. Hong Kong Green) using 2D-DIGE. Food Chemistry, 148, 155-161. PMid:24262540. http://dx.doi.org/10.1016/j.foodchem.2013.10.025

Ng, Z. X., \& Tan, W. C. (2017). Impact of optimised cooking on the antioxidant activity in edible mushrooms. Journal of Food Science and Technology-Mysore, 54(12), 4100-4111. PMid:29085153. http://dx.doi.org/10.1007/s13197-017-2885-0

Ng, Z. X., \& Rosman, N. F. (2019). In vitro digestion and domestic cooking improved the total antioxidant activity and carbohydrate-digestive enzymes inhibitory potential of selected edible mushrooms. Journal of Food Food Science and Technology-mysore, 56(2), 865-877. PMid:30906044. http://dx.doi.org/10.1007/s13197-018-3547-6

Ng, Z. X., \& See, A. N. (2019). Effect of in vitro digestion on the total polyphenol and flavonoid, antioxidant activity and carbohydrate hydrolysing enzymes inhibitory potential of selected functional plant-based foods. Journal of Food Processing and Preservation, 43(4), e13903. http://dx.doi.org/10.1111/jfpp.13903

Somsub, W., Kongkachuichai, R., Sungpuag, P., \& Charoensiri, R. (2008). Effects of three conventional cooking methods on vitamin C, tannin, myo-inositol phosphates contents in selected Thai vegetables. Journal of Food Composition and Analysis, 21(2), 187-197. http://dx.doi.org/10.1016/j.jfca.2007.08.002

Subramaniam, S., Rosdi, M. H. B., \& Kuppusamy, U. R. (2017). Customized cooking methods enhance antioxidant, antiglycemic, and insulin-like properties of Momordica charantia and Moringa oleifera. Journal of Food Quality, 2017, 1-9. http://dx.doi.org/10.1155/2017/9561325

Suresh, D., Manjunatha, H., \& Srinivasan, K. (2007). Effect of heat processing of spices on the concentrations of their bioactive principles: Turmeric (Curcuma longa), red pepper (Capsicum annuum) and black pepper (Piper nigrum). Journal of Food Composition and Analysis, 20(3-4), 346-351. http://dx.doi.org/10.1016/j.jfca.2006.10.002

Szeto, Y. T., Tomlinson, B., \& Benzie, I. F. (2002). Total antioxidant and ascorbic acid content of fresh fruits and vegetables: Implications for dietary planning and food preservation. British Journal of Nutrition, 87(1), 55-59. PMid:11898770. http://dx.doi.org/10.1079/BJN2001483

Valko, M., Rhodes, C. J., Moncol, J., Izakovic, M., \& Mazur, M. (2006). Free radicals, metals and antioxidants in oxidative stress-induced cancer. Chemico-Biological Interactions, 160(1), 1-40. PMid:16430879. http://dx.doi.org/10.1016/j.cbi.2005.12.009

Wawire, M., Oey, I., Mathooko, F., Njoroge, C., Shitanda, D., \& Hendrickx, M. (2011). Thermal stability of ascorbic acid and ascorbic acid oxidase in african cowpea leaves (Vigna unguiculata) of different maturities. Journal of Agricultural and Food Chemistry, 59(5), 1774-1783. PMid:21309563. http://dx.doi.org/10.1021/jf103469n

Zhang, D. L., \& Hamauzu, Y. (2004). Phenolics, ascorbic acid, carotenoids and antioxidant activity of broccoli and their changes during conventional and microwave cooking. Food Chemistry, 88(4), 503-509. http://dx.doi.org/10.1016/j.foodchem.2004.01.065 
Effects of different heat treatments on the antioxidant activity and ascorbic acid content of bitter melon, Momordica charantia Ng, Z. X., \& Kuppusamy, U. R.

Funding: This work was supported by University of Malaya High Impact Research Grant (MOHE/UM-HIR E000042-20001), Fundamental Research Grant Scheme (FRGS/1/2019/SKK06/UNIM/02/1) and University of Nottingham Malaysia FOS Pump Priming fund(P071/17).

Received: Oct. 11, 2018; Accepted: June 03, 2019 